\title{
A novel hydrogen-bonded cyclic dibromide in an organic diammonium salt $^{\#}$
}

\author{
BIKSHANDARKOIL R SRINIVASAN, ${ }^{1, *}$ SUNDER N DHURI, ${ }^{1}$ JYOTI V SAWANT, ${ }^{1}$ \\ CHRISTIAN NÄTHER ${ }^{2}$ and WOLFGANG BENSCH ${ }^{2}$ \\ ${ }^{1}$ Department of Chemistry, Goa University PO, Goa 403206 \\ ${ }^{2}$ Institut für Anorganische Chemie, Christian-Albrechts-Universität Kiel, Olshausenstraße 40, D-24098 \\ Kiel, Germany \\ e-mail: srini@unigoa.ac.in
}

MS received 23 September 2005; revised 2 January 2006

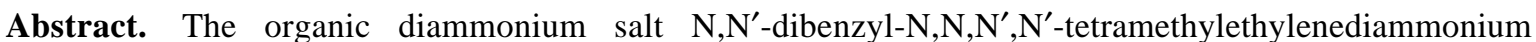
dibromide dihydrate, (dbtmen) $\mathrm{Br}_{2} \cdot 2 \mathrm{H}_{2} \mathrm{O}(\mathbf{1})$, was prepared by the reaction of $\mathrm{N}, \mathrm{N}, \mathrm{N}^{\prime}, \mathrm{N}^{\prime}$-tetramethylethylenediamine (tmen) with benzyl bromide. 1 crystallizes in the triclinic space group $P \overline{1}$ with the following unit cell dimensions for $\mathrm{C}_{20} \mathrm{H}_{34} \mathrm{Br}_{2} \mathrm{~N}_{2} \mathrm{O}_{2}(\mathrm{M}=494.31): a=8.6672(6) \AA, b=11.7046(8) \AA, c=$ $11.7731(8) \AA, \alpha=76.988(8)^{\circ}, \beta=88.978(8)^{\circ}, \gamma=76.198(8)^{\circ}, V=1129.26(13) \AA^{3}, Z=2$. Three components, namely the (dbtmen) ${ }^{2+}$ dication, two bromide anions and two crystal water molecules constitute the structural arrangement of $\mathbf{1} . \mathrm{H}_{2} \mathrm{O}$ molecules are linked to bromide anions via $\mathrm{O}-\mathrm{H} \cdots \mathrm{Br}$ hydrogen bonding interactions resulting in the formation of a four-membered $\left\{\mathrm{O}_{2} \mathrm{Br}_{2}\right\}$ cyclic dibromide. The $\left\{\mathrm{O}_{2} \mathrm{Br}_{2}\right\}$ units and the dications are arranged as alternating layers extending in the crystallographic $b c$ plane. The arrangement of anions and cations may be viewed as a typical lamellar structure. The crystal water molecules can be removed by heating 1 at $140^{\circ} \mathrm{C}$ and the anhydrous dibromide thus formed can be fully rehydrated as evidenced by IR spectra and X-ray powder patterns.
\end{abstract}

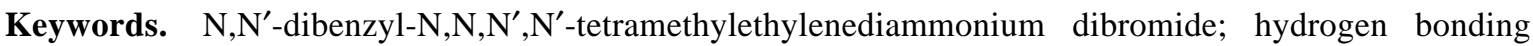
interactions; cyclic dibromide.

\section{Introduction}

In recent years, organic amines have been extensively used as structure-directing agents for the construction of novel supramolecular assemblies as evidenced by the structural characterization of several new materials, which exhibit interesting molecular architectures. The important as well as often observed structural features in several of these compounds are the weak $\mathrm{H}$-bonding interactions between the organic amine/ammonium cation and the crystal or coordinated water or other electronegative sites in the rest of the molecule. $\mathrm{N}-\mathrm{H} \cdots \mathrm{O}$ or $\mathrm{O}-\mathrm{H} \cdots \mathrm{N}$ hydrogen bonding interactions give rise to a variety of structurally diverse materials ${ }^{1}$ that trap small clusters of water molecules in the host lattice. ${ }^{2-5}$ In this context, organic diamines like $\mathrm{N}, \mathrm{N}, \mathrm{N}^{\prime}, \mathrm{N}^{\prime}$-tetramethylethyl-

\footnotetext{
*For correspondence

\#Dedicated to Prof S Chandrasekaran on the occasion of his 60th birthday
}

enediamine (tmen), 1,3-propanediamine (1,3-pn), piperazine (pip) etc. have been shown to be useful structure directors for the synthesis of novel polyoxomolybdates as well as a variety of open-framework metal phosphates and metal carboxylates. ${ }^{6-10}$ The usefulness of the weak $\mathrm{N}-\mathrm{H} \cdots \mathrm{O}$ bonding interactions for the formation of unusual structural architecture has been recently demonstrated in the case of a hydrated mono perchlorate salt of $o$-phenylenediamine. ${ }^{11}$ In this compound the perchlorate anion, the monoprotonated $o$-phenylenediamine cation and the crystal water assemble with the aid of $\mathrm{N}-\mathrm{H} \cdots \mathrm{O}$ as well as $\mathrm{O}-\mathrm{H} \cdots \mathrm{O}$ hydrogen bonding interactions into a unique hydrogen-bonded network consisting of a hydrophobic double layer with a hydrophilic gallery in it.

In our research, we investigate the reactions of organic diamines with group VI oxo and thiometalates and have synthesized and structurally characterized several oxochromates, ${ }^{12-14}$ tetrathiomolybdates ${ }^{15-19}$ and tetrathiotungstates. ${ }^{20-24}$ These sub- 
stances exhibit weak $\mathrm{H}$-bonding interactions in the form of $\mathrm{N}-\mathrm{H} \cdots \mathrm{X}(\mathrm{X}=\mathrm{O}$ or $\mathrm{S})$ bonds between the organic cation and the oxochromate or tetrathiometalate anions. In all the tetrathiomolybdate and tetrathiotungstate compounds $\left[\mathrm{MS}_{4}\right]^{2-}(\mathrm{M}=\mathrm{Mo}, \mathrm{W})$ structurally characterized by us, we have observed that one or two of the $\mathrm{M}-\mathrm{S}$ bonds are elongated, which is attributed to H-bonding interactions. Our work with $\left[\mathrm{WS}_{4}\right]^{2-}$ has shown that organic amines can be used as cationic handles to distort the $\left[\mathrm{WS}_{4}\right]^{2-}$ tetrahedron by varying the $\mathrm{H}$-bonding interactions. ${ }^{24}$ In order to understand the importance of H-bonding interactions in the structural chemistry of tetrathiotungstates, we investigated the reactions of $\left[\mathrm{WS}_{4}\right]^{2-}$ with organic amines which differ in terms of their steric bulk and the number of potential $\mathrm{H}$ donor atoms. During the course of this investigation, a fully alkylated diammonium dihalide was sought as a precursor for the synthesis of a reference $\left[\mathrm{WS}_{4}\right]^{2-}$ compound that should be devoid of cation-anion interactions in the form of weak H-bonding interactions. Such a tetraalkylated salt $\mathbf{1}$ was prepared by benzylating tmen. Interestingly, a structure determination of 1 revealed the presence of a hydrogen bonded cyclic dibromide unit. Further, the title compound can be reversibly hydrated. We wish to present the results of these investigations in this paper.

\section{Experimental}

All the chemicals used in this study were of reagent grade and used as received. Infrared spectra were recorded on a Shimadzu FT-IR spectrometer (IRPrestige-21) in the range $4000-400 \mathrm{~cm}^{-1}$. The samples were prepared as $\mathrm{KBr}$ diluted pellets in the solid state and the infrared signals referenced to polystyrene bands. Electronic spectra were recorded in water using matched quartz cells on a Shimadzu (UV2450) spectrophotometer. X-ray powder pattern were recorded on an ITAL System (APD 2000) Xray diffractometer using $\mathrm{Cu}-\mathrm{K} \alpha$ radiation. TG-DTA studies were performed in $\mathrm{Ar}$ atmosphere in the temperature range $20^{\circ} \mathrm{C}$ to $500^{\circ} \mathrm{C}$ on a Netzsch simultaneous thermal analyses apparatus. A heating rate of $4^{\circ} \mathrm{C} / \mathrm{min}$ was chosen for the measurement.

\subsection{Preparation of (dbtmen) $\mathrm{Br}_{2} \cdot 2 \mathrm{H}_{2} \mathrm{O} 1$}

The diamine tmen $(1.3 \mathrm{ml})$ was dissolved in $\sim 10 \mathrm{ml}$ of $\mathrm{CH}_{3} \mathrm{CN}$. This diluted amine solution was cooled and benzyl bromide $(2.3 \mathrm{ml})$ was added in drops with continuous stirring over 10-15 min. (Caution! Benzyl bromide is lachrymatory and hence the reaction has to be performed in a well-ventilated fume cupboard.) When addition is complete, copious amounts of white crystalline solid slowly separated out. The crystalline product was isolated by filtration, washed with isopropanol $(20 \mathrm{ml})$, followed by ether $(20 \mathrm{ml})$ and finally dried in air. Yield $(4 \cdot 0 \mathrm{~g})$. Crystallisation of this material from water afforded $\mathrm{X}$ ray quality crystals of (dbtmen) $\mathrm{Br}_{2} \cdot 2 \mathrm{H}_{2} \mathrm{O}$.

Analysis - found (calc) for $\mathrm{C}_{20} \mathrm{H}_{30} \mathrm{~N}_{2} \mathrm{Br}_{2} \cdot 2 \mathrm{H}_{2} \mathrm{O}: \mathrm{C}$ 48.63 (48.59), H 7.01 (6.95), N 5.68 (5.67)\%.

IR data in $\mathrm{cm}^{-1}: 3464(s), 3394(s), 3226(w)$, $3020(s), 3007(s h), 1616(m), 1485(s), 1463(s)$, $1454(s), 1396(w), 1355(w), 1213(m), 1080(w)$, $1033(w), 995(m), 964(w), 941(m), 921(m), 893$ $(m), 864(s), 786(s), 744(s), 729(s), 713(s), 578$ $(s), 513(w), 495(w), 462(w)$.

UV-Vis data (water): $262 \mathrm{~nm}\left(\stackrel{\circ}{a}=6401 \mathrm{~mol}^{-1} \mathrm{~cm}^{-1}\right)$.

${ }^{1} \mathrm{H}$ NMR $\left(\mathrm{D}_{2} \mathrm{O}-d_{6}\right)(\delta$ in ppm): $7.44(s, 10 \mathrm{H}), 4.53$ $(s, 4 \mathrm{H}), 3.91(s, 4 \mathrm{H}), 3.06(s, 12 \mathrm{H})$.

\subsection{Preparation of (dbtmen) $\mathrm{Br}_{2} 2$}

A powdered sample of $1(0.488 \mathrm{~g})$ was heated in a temperature controlled oven at $140^{\circ} \mathrm{C}$ for $\sim 20 \mathrm{~min}$. This resulted in the formation of the anhydrous compound. The observed mass loss of $7.65 \%$ is in very good agreement with the expected value (7.29\%) for the loss of two moles of water.

IR data in $\mathrm{cm}^{-1}: 3026(\mathrm{~m}), 2981(\mathrm{~s}), 2885(w), 2804$ $(w), 1581(w), 1469(s), 1448(s), 1398(m), 1361$ $(w), 1219(m), 1076(w), 1003(m), 975(m), 927(s)$, $891(s), 867(\mathrm{~s}), 842(w), 821(w), 779(s), 721(s)$, $702(s), 619(\mathrm{w}), 513(w), 486(w), 462(w)$.

\subsection{Reversible hydration studies}

The anhydrous compound 2 was prepared as mentioned above. A powdered sample of the water-free compound $(0.451 \mathrm{~g})$ was equilibriated over water in a dessicator for $\sim 30 \mathrm{~min}$. This resulted in the formation of the starting dihydrate $\mathbf{1}$ in quantitative yield. The IR spectrum of the rehydrated product is identical to that of $\mathbf{1}$.

\subsection{Single crystal X-ray diffractometry}

Intensity data for $\mathbf{1}$ were collected on a Stoe Image Plate Diffraction System using graphite monochro- 
mated $\mathrm{Mo}-\mathrm{K}_{\alpha}$ radiation at $170 \mathrm{~K}$. The intensities were corrected for Lorentz polarization effects. The structure was solved with direct methods using SHELXS- $97^{25}$ and refinement was done against $F^{2}$ using SHELXL-97. ${ }^{26}$ All non-hydrogen atoms were refined using anisotropic displacement parameters. The hydrogen atoms were positioned with idealized geometry and refined using the riding model with fixed isotropic displacement parameters. The technical details of data acquisition and some selected crystal refinement results are summarized in table 1. Crystallographic data (excluding structure factors) for the structure reported in this paper has been deposited with the Cambridge Crystallographic Data Centre as supplementary publication no. CCDC 284867 (1). Copies of the data can be obtained, free of charge, on application to CCDC, 12 Union Road, Cambridge CB2 1 EZ, UK. (fax: +44-(0)1223-336033 or email: deposit@ccdc.cam.ac.uk).

Table 1. Technical details of data acquisition and selected refinement results for (dbtmen) $\mathrm{Br}_{2} \cdot 2 \mathrm{H}_{2} \mathrm{O}, \mathbf{1}$.

\begin{tabular}{|c|c|}
\hline Compound & (dbtmen) $\mathrm{Br}_{2} \cdot 2 \mathrm{H}_{2} \mathrm{O}(\mathbf{1})$ \\
\hline Formula & $\mathrm{C}_{20} \mathrm{H}_{34} \mathrm{Br}_{2} \mathrm{~N}_{2} \mathrm{~N}_{2} \mathrm{O}_{2}$ \\
\hline Temperature $[\mathrm{K}]$ & $170(2)$ \\
\hline Wavelength [pm] & 71.073 \\
\hline Space group & $P \overline{1}$ \\
\hline$a[\AA]$ & $8.6672(6)$ \\
\hline$b[\AA]$ & $11 \cdot 7046(8)$ \\
\hline$c[\AA]$ & $11 \cdot 7731(8)$ \\
\hline$\alpha\left[^{0}\right]$ & $76 \cdot 988(8)$ \\
\hline$\beta\left[{ }^{\mathrm{o}}\right]$ & $88.978(8)$ \\
\hline$\gamma\left[{ }^{\mathrm{O}}\right]$ & $76 \cdot 198(8)$ \\
\hline Volume $\left[\AA^{3}\right]$ & $1129 \cdot 26(13)$ \\
\hline$Z$ & 2 \\
\hline$\mu\left[\mathrm{mm}^{-1}\right]$ & $3 \cdot 605$ \\
\hline$F(000)$ & 508 \\
\hline Molecular weight [g/mol] & $494 \cdot 31$ \\
\hline Density (calcd.) $\left[\mathrm{g} \mathrm{cm}^{-3}\right]$ & 1.454 \\
\hline Crystal size (in mm) & $0.5 \times 0.2 \times 0.2$ \\
\hline$h k l$ range & $-11 / 11 ;-15 / 15 ;-15 / 15$ \\
\hline $2 \theta$ range & $4 \cdot 5^{\circ}-56^{\circ}$ \\
\hline Reflections collected & 9858 \\
\hline Reflections unique & 5133 \\
\hline $\operatorname{Data}\left(F_{\mathrm{O}}>4 \sigma\left(F_{\mathrm{O}}\right)\right)$ & 4162 \\
\hline$R_{\text {int }}$ & $0 \cdot 0319$ \\
\hline Min/Max transmission & $0.5628 / 0 \cdot 6349$ \\
\hline$\rho\left[\mathrm{e} / \AA^{3}\right]$ & $-0 \cdot 721 / 0 \cdot 464$ \\
\hline Parameters & 236 \\
\hline$R 1\left[F_{\mathrm{O}}>4 \sigma\left(F_{\mathrm{O}}\right)\right]^{\mathrm{a}}$ & 0.0297 \\
\hline$W R 2$ for all unique data & $0 \cdot 0760$ \\
\hline Goodness of fit & 1.007 \\
\hline
\end{tabular}

${ }^{\mathrm{a}} R 1=\Sigma|| F_{\mathrm{O}}|-| F \mathrm{c}|| \Sigma\left|F_{\mathrm{O}}\right|$

\section{Results and discussion}

Synthesis of the organic diammonium salt 1 was accomplished by reacting the organic diamine tmen with benzyl bromide in a 1:2 molar ratio in $\mathrm{CH}_{3} \mathrm{CN}$ followed by recrystallisation from water. The compound analysed satisfactorily for the proposed formula. Reaction of 1 with $\left(\mathrm{NH}_{4}\right)_{2}\left[\mathrm{WS}_{4}\right]$ afforded the highly insoluble complex (dbtmen) $\left[\mathrm{WS}_{4}\right]$. The high insolubility of this compound in aqueous as well as non-aqueous solvents including DMF and DMSO precluded the preparation of a suitable crystalline material for single-crystal structure investigations. However, the presence of the organic cation as well as $\left[\mathrm{WS}_{4}\right]^{2-}$ could be inferred from IR spectra and the formulation is consistent with analytical data.

The electronic spectrum of $\mathbf{1}$ exhibits a signal at $\sim 260 \mathrm{~nm}$ which can be assigned to the charge transfer of the aromatic moiety. The proton magnetic resonance spectrum of $\mathbf{1}$ exhibits four sharp singlets at $\delta$ $7.44(s, 10 \mathrm{H}), \delta 4.53(s, 4 \mathrm{H}), \delta 3.91(s, 4 \mathrm{H}), 3.06 \mathrm{ppm}$ $(s, 12 \mathrm{H})$, which can be assigned to the resonance absorptions of the aromatic, benzylic, methylene and methyl protons respectively. The IR spectrum of the hydrated dibromide exhibits strong bands at 3464, $3394 \mathrm{~cm}^{-1}$ assignable to the stretching vibration of $\mathrm{O}-\mathrm{H}$, while the $\mathrm{O}-\mathrm{H}$ bending vibration was located at $1616 \mathrm{~cm}^{-1}$. Several bands in the mid IR region can be attributed to the vibrations of the organic cation. 1 can be dehydrated to form the corresponding anhydrous compound by heating at $\sim 140^{\circ} \mathrm{C}$. Formation of the water-free compound $\mathbf{2}$ can be evidenced from the IR spectrum of calcined $\mathbf{1}$, which is devoid of the $\mathrm{O}-\mathrm{H}$ bands at 3464,3394 and $1616 \mathrm{~cm}^{-1}$.

The organic dibromide dihydrate 1 crystallizes in the triclinic space group $P \overline{1}$ (table 1) with all atoms located in general positions. The asymmetric unit of

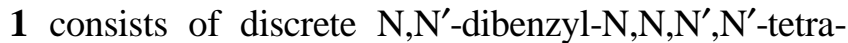
methylethylenediammonium cations, two bromide ions and two crystal water molecules (figure 1). Selected bond lengths and bond angles are collected in table 2. The observed $\mathrm{C}-\mathrm{C}$ and $\mathrm{C}-\mathrm{N}$ bond lengths are in good agreement with those found in other compounds containing the tmen moiety. ${ }^{17,20,27}$ The crystal water molecules in $\mathbf{1}$ are hydrogen-bonded with two bromide ions forming a novel fourmembered cyclic dibromide $\left\{\mathrm{O}_{2} \mathrm{Br}_{2}\right\}$ (only the $\mathrm{O}$ and $\mathrm{Br}$ but not the $\mathrm{H}$ atoms are considered) (figure 2). The two bromide ions are linked to $\mathrm{H}_{2} \mathrm{O}$ via four O$\mathrm{H}$ * Br hydrogen bonds ranging from 2.472 to $2.528 \AA$ $\mathrm{Br} \cdots \mathrm{H}$ distances are quite short compared to $3.05 \AA$, 
the sum of the van der Waals radii ${ }^{28}$ of $\mathrm{Br}$ and $\mathrm{H}$. The details of the H-bonding parameters are summarized in table 3 . Both $\mathrm{Br} 1$ and $\mathrm{Br} 2$ are involved in two $\mathrm{O}-\mathrm{H} \cdots \mathrm{Br}$ interactions each. The large values of the $\mathrm{O}-\mathrm{H} \cdots \mathrm{Br}$ angles indicate that these bonds are quite strong which is further evident from the values of the $\mathrm{Br} \cdots \mathrm{O}$ distances ranging from 3.306 to $3.359 \AA$. As a result of these $\mathrm{H}$-bonds, alternating layers of the organic cation and the cyclic hydrogen-bonded

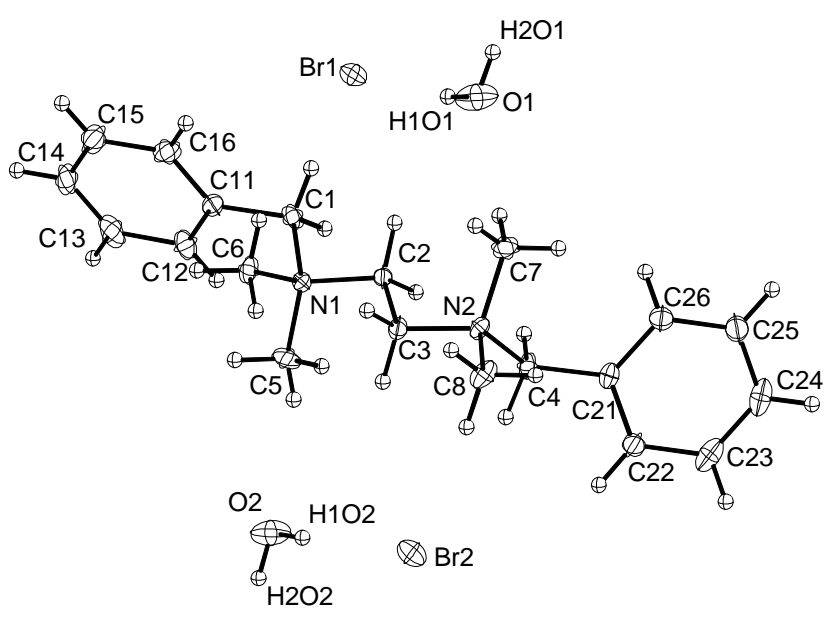

Figure 1. Crystal structure of (dbtmen) $\mathrm{Br}_{2} \cdot 2 \mathrm{H}_{2} \mathrm{O}$ (1) with labeling and displacement ellipsoids drawn at the $50 \%$ probability level.

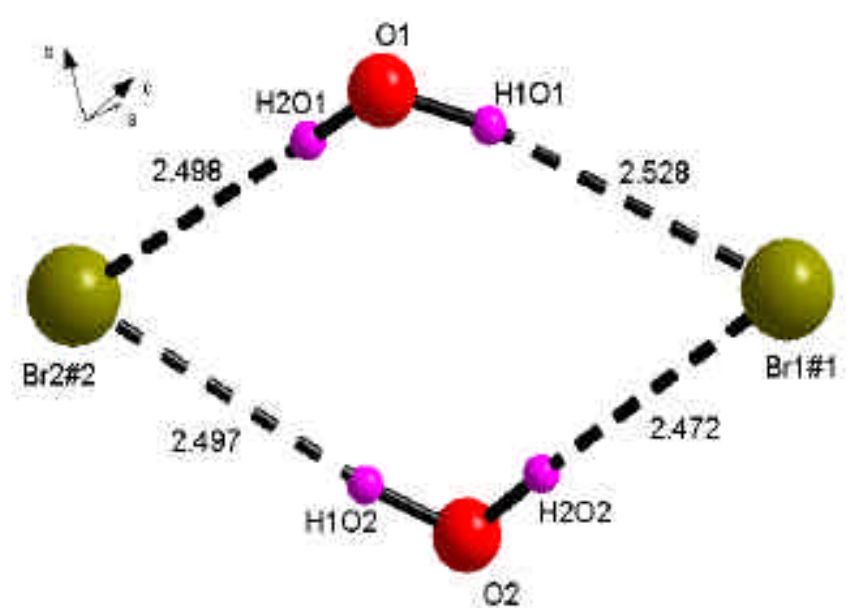

Figure 2. View of the four-membered cyclic dibromide along $a$ axis showing $\mathrm{O}-\mathrm{H} \cdots \mathrm{Br}$ interactions (given are the intermolecular $\mathrm{O}-\mathrm{H} \cdots \mathrm{Br}$ distances in $\AA$ and dashed lines indicate hydrogen bonding). Colour codes: $\mathrm{O}$ red, $\mathrm{Br}$ green and $\mathrm{H}$ purple [symmetry codes: $\# 1=x, y, z+1$, $\# 2=x, y, z-1]$. dibromides are formed extending in the crystallographic $b c$ plane. A search of the Cambridge structure database for organic bromides revealed that similar hydrogen-bonded bromide units have also been reported earlier in some imidazolium and pyridinium bromides. ${ }^{29-35} \mathrm{O} \cdots \mathrm{Br}$ distances, which are of the order of 3.293 to $3.363 \AA$ in these compounds, are comparable with the observed values for 1. To the best of our knowledge, the present structure constitutes the first example of such a unit in a tetraalkyldiammonium dibromide. In the unbenzylated compound $\left(\operatorname{tmenH} \mathrm{H}_{2}\right) \mathrm{Br}_{2}$ it has been reported that the cation is linked to the anion via $\mathrm{N}-\mathrm{H} \cdots \mathrm{Br}$

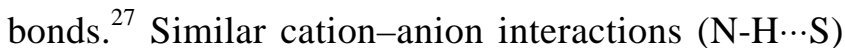
have also been observed in $\left(\mathrm{tmenH}_{2}\right)\left[\mathrm{MoS}_{4}\right] .{ }^{17}$ In view of the tetraalkylation of the $\mathrm{N}$ atom no $\mathrm{N}-\mathrm{H} \cdots \mathrm{X}$ interactions are possible in $\mathbf{1}$. Hence the formation of the layer structure of $\mathbf{1}$ can be attributed to the tetraalkylation of $\mathrm{N}$. In $\mathbf{1}$ the interlayer interactions between the anions and cations can be of van der Waals type and/or electrostatic in nature as no interactions are observed other than the $\mathrm{O}-\mathrm{H} \cdots \mathrm{Br}$ bonds. A view of (dbtmen) $\mathrm{Br}_{2} \cdot 2 \mathrm{H}_{2} \mathrm{O}$ showing the alternating layers of cations and anions in the [010] plane is depicted in figure 3 . The phenyl rings in each layer are arranged one below the other. The perpendicular distance between adjacent phenyl rings in the alternating layers is about $4.697 \AA$, which indicates the

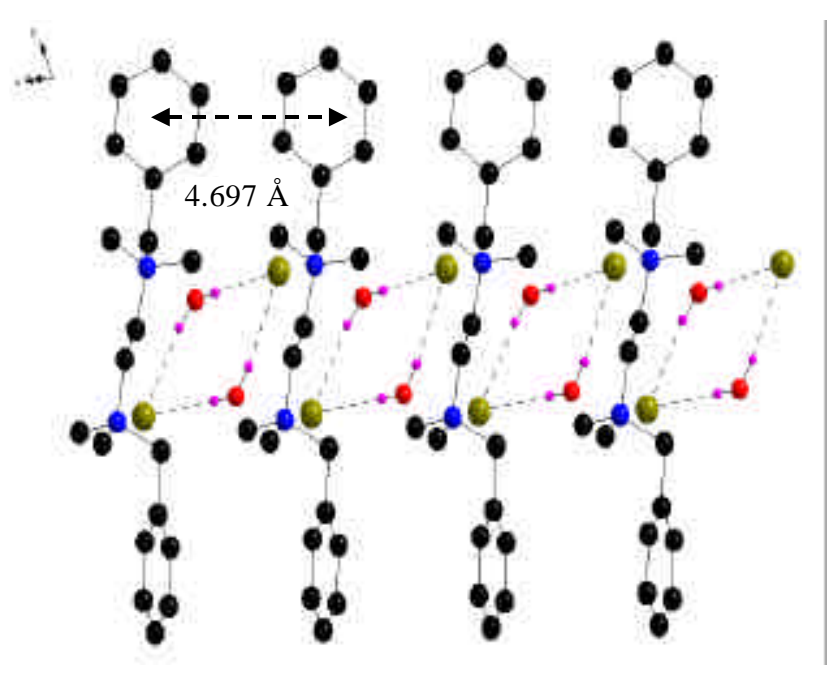

Figure 3. View of compound $\mathbf{1}$ showing alternating layers of organic (dbtmen) ${ }^{2+}$ cations (dashed lines indicate hydrogen bonding). The $\mathrm{H}$ atoms of the (dbtmen $)^{2+}$ cation are omitted for clarity. The perpendicular distance of $4.697 \AA$ between the rings indicates absence of stacking interactions. Colour codes: $\mathrm{C}$ black, $\mathrm{N}$ blue, $\mathrm{O}$ red, $\mathrm{Br}$ green and $\mathrm{H}$ purple. 


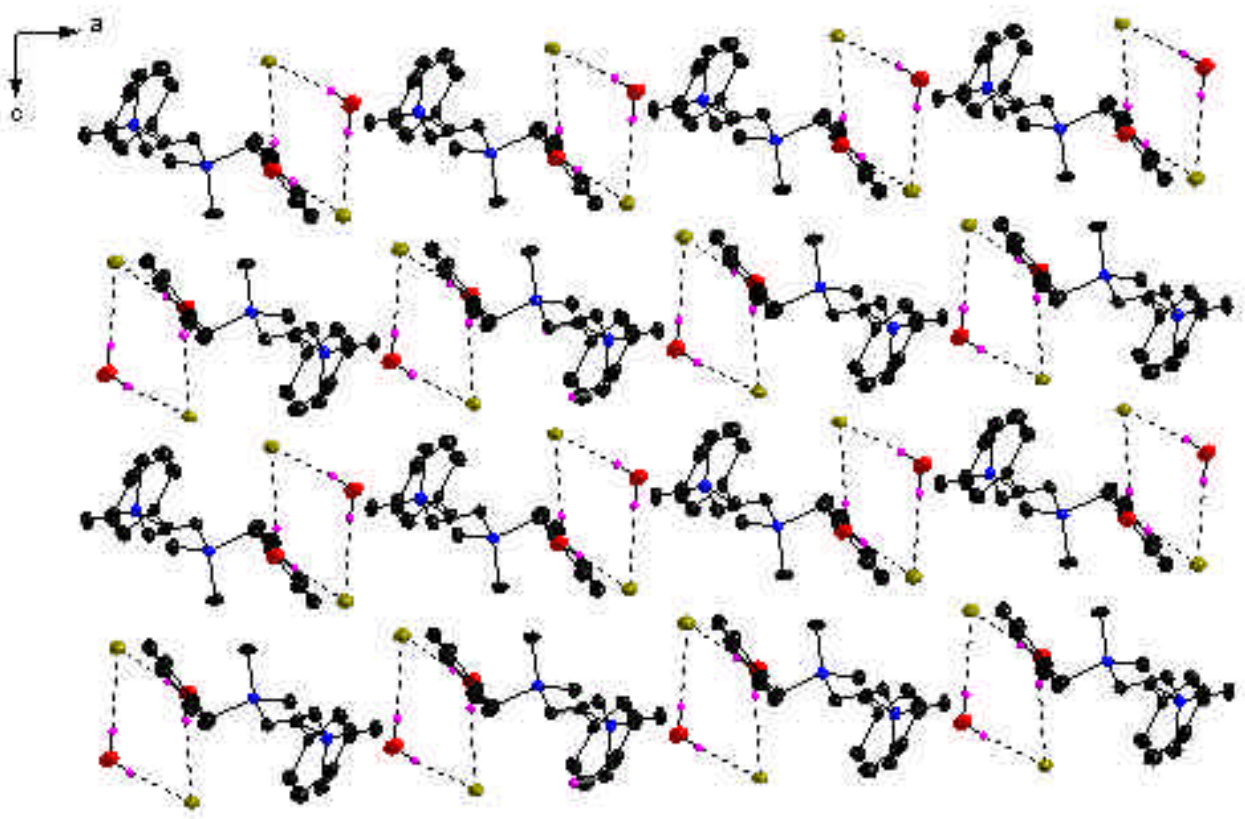

Figure 4. Hydrogen bonded cyclic dibromides occupying the pores between alternating layers of organic cations in the crystallographic ac plane. The $\mathrm{H}$ atoms of the organic cation are not shown. Colour codes: $\mathrm{C}$ black, $\mathrm{N}$ blue, $\mathrm{O}$ red, $\mathrm{Br}$ green and $\mathrm{H}$ purple.

Table 2. Selected geometric parameters (Å, degrees) for (dbtmen) $\mathrm{Br}_{2} \cdot 2 \mathrm{H}_{2} \mathrm{O}, \mathbf{1}$.

\begin{tabular}{|c|c|c|c|}
\hline \multicolumn{4}{|l|}{ Bond lengths } \\
\hline $\mathrm{C}(1)-\mathrm{C}(11)$ & $1 \cdot 513(3)$ & $\mathrm{C}(11)-\mathrm{C}(12)$ & $1 \cdot 396(3)$ \\
\hline $\mathrm{C}(1)-\mathrm{N}(1)$ & $1 \cdot 540(3)$ & $\mathrm{C}(12)-\mathrm{C}(13)$ & $1 \cdot 400(3)$ \\
\hline $\mathrm{N}(1)-\mathrm{C}(6)$ & $1 \cdot 500(3)$ & $\mathrm{C}(13)-\mathrm{C}(14)$ & $1 \cdot 379(4)$ \\
\hline $\mathrm{N}(1)-\mathrm{C}(5)$ & $1 \cdot 502(2)$ & $\mathrm{C}(14)-\mathrm{C}(15)$ & $1 \cdot 387(4)$ \\
\hline $\mathrm{N}(1)-\mathrm{C}(2)$ & $1 \cdot 517(2)$ & $C(15)-C(16)$ & $1 \cdot 394(3)$ \\
\hline$C(2)-C(3)$ & $1 \cdot 530(3)$ & $C(21)-C(26)$ & $1 \cdot 391(3)$ \\
\hline $\mathrm{C}(3)-\mathrm{N}(2)$ & $1 \cdot 517(2)$ & $\mathrm{C}(21)-\mathrm{C}(22)$ & $1.400(3)$ \\
\hline $\mathrm{N}(2)-\mathrm{C}(7)$ & $1 \cdot 506(3)$ & $\mathrm{C}(22)-\mathrm{C}(23)$ & $1 \cdot 393(3)$ \\
\hline $\mathrm{N}(2)-\mathrm{C}(8)$ & $1 \cdot 506(3)$ & $\mathrm{C}(23)-\mathrm{C}(24)$ & $1 \cdot 378(4)$ \\
\hline $\mathrm{N}(2)-\mathrm{C}(4)$ & $1 \cdot 528(3)$ & $C(26)-C(25)$ & $1 \cdot 391(3)$ \\
\hline $\mathrm{C}(4)-\mathrm{C}(21)$ & $1 \cdot 511(3)$ & $\mathrm{C}(24)-\mathrm{C}(25)$ & $1 \cdot 394(4)$ \\
\hline $\mathrm{C}(11)-\mathrm{C}(16)$ & $1 \cdot 392(3)$ & & \\
\hline \multicolumn{4}{|l|}{ Bond angles } \\
\hline $\mathrm{C}(11)-\mathrm{C}(1)-\mathrm{N}(1)$ & $114 \cdot 10(17)$ & $\mathrm{C}(16)-\mathrm{C}(11)-\mathrm{C}(12)$ & $119 \cdot 51(19)$ \\
\hline $\mathrm{C}(6)-\mathrm{N}(1)-\mathrm{C}(5)$ & $109 \cdot 56(17)$ & $\mathrm{C}(16)-\mathrm{C}(11)-\mathrm{C}(1)$ & $119.78(19)$ \\
\hline $\mathrm{C}(6)-\mathrm{N}(1)-\mathrm{C}(2)$ & $110 \cdot 85(15)$ & $\mathrm{C}(12)-\mathrm{C}(11)-\mathrm{C}(1)$ & $120 \cdot 6(2)$ \\
\hline $\mathrm{C}(5)-\mathrm{N}(1)-\mathrm{C}(2)$ & $110 \cdot 38(16)$ & $\mathrm{C}(11)-\mathrm{C}(12)-\mathrm{C}(13)$ & $119 \cdot 7(2)$ \\
\hline $\mathrm{C}(6)-\mathrm{N}(1)-\mathrm{C}(1)$ & $110 \cdot 41(16)$ & $\mathrm{C}(14)-\mathrm{C}(13)-\mathrm{C}(12)$ & $120 \cdot 1(2)$ \\
\hline $\mathrm{C}(5)-\mathrm{N}(1)-\mathrm{C}(1)$ & $110 \cdot 32(16)$ & $\mathrm{C}(13)-\mathrm{C}(14)-\mathrm{C}(15)$ & $120 \cdot 5(2)$ \\
\hline $\mathrm{C}(2)-\mathrm{N}(1)-\mathrm{C}(1)$ & $105 \cdot 26(15)$ & $\mathrm{C}(14)-\mathrm{C}(15)-\mathrm{C}(16)$ & $119 \cdot 7(2)$ \\
\hline $\mathrm{N}(1)-\mathrm{C}(2)-\mathrm{C}(3)$ & $112 \cdot 09(17)$ & $\mathrm{C}(11)-\mathrm{C}(16)-\mathrm{C}(15)$ & $120 \cdot 4(2)$ \\
\hline$N(2)-C(3)-C(2)$ & $112.69(17)$ & $\mathrm{C}(26)-\mathrm{C}(21)-\mathrm{C}(22)$ & $119 \cdot 06(19)$ \\
\hline $\mathrm{C}(7)-\mathrm{N}(2)-\mathrm{C}(8)$ & $108 \cdot 49(16)$ & $\mathrm{C}(26)-\mathrm{C}(21)-\mathrm{C}(4)$ & $120 \cdot 97$ (19) \\
\hline $\mathrm{C}(7)-\mathrm{N}(2)-\mathrm{C}(3)$ & $110 \cdot 46(15)$ & $\mathrm{C}(22)-\mathrm{C}(21)-\mathrm{C}(4)$ & $119.9(2)$ \\
\hline $\mathrm{C}(8)-\mathrm{N}(2)-\mathrm{C}(3)$ & $106 \cdot 02(17)$ & $\mathrm{C}(23)-\mathrm{C}(22)-\mathrm{C}(21)$ & $120 \cdot 1(2)$ \\
\hline $\mathrm{C}(7)-\mathrm{N}(2)-\mathrm{C}(4)$ & $111 \cdot 53(17)$ & $\mathrm{C}(24)-\mathrm{C}(23)-\mathrm{C}(22)$ & $120 \cdot 4(2)$ \\
\hline $\mathrm{C}(8)-\mathrm{N}(2)-\mathrm{C}(4)$ & $110 \cdot 58(15)$ & $\mathrm{C}(25)-\mathrm{C}(26)-\mathrm{C}(21)$ & $120 \cdot 6(2)$ \\
\hline $\mathrm{C}(3)-\mathrm{N}(2)-\mathrm{C}(4)$ & $109 \cdot 63(15)$ & $\mathrm{C}(23)-\mathrm{C}(24)-\mathrm{C}(25)$ & $119 \cdot 9(2)$ \\
\hline $\mathrm{C}(21)-\mathrm{C}(4)-\mathrm{N}(2)$ & $114 \cdot 27(16)$ & $\mathrm{C}(26)-\mathrm{C}(25)-\mathrm{C}(24)$ & $119 \cdot 9(2)$ \\
\hline
\end{tabular}


absence of stacking interactions. The two phenyl rings in each cation are perpendicular to each other, which is evident from figure 4 where a view of the structure along the $b$ axis is shown.

The thermal stability of (dbtmen) $\mathrm{Br}_{2} \cdot 2 \mathrm{H}_{2} \mathrm{O}$ was investigated using DTA-TG measurements. On heating, the compound starts emitting water at around $90^{\circ} \mathrm{C}$, which is accompanied by a sharp endothermic event in DTA curve at $111^{\circ} \mathrm{C}$ (figure 5). A single mass step of $7.4 \%$ (expected mass loss is $7.3 \%$ ) can be attributed to the emission of two moles of crystal

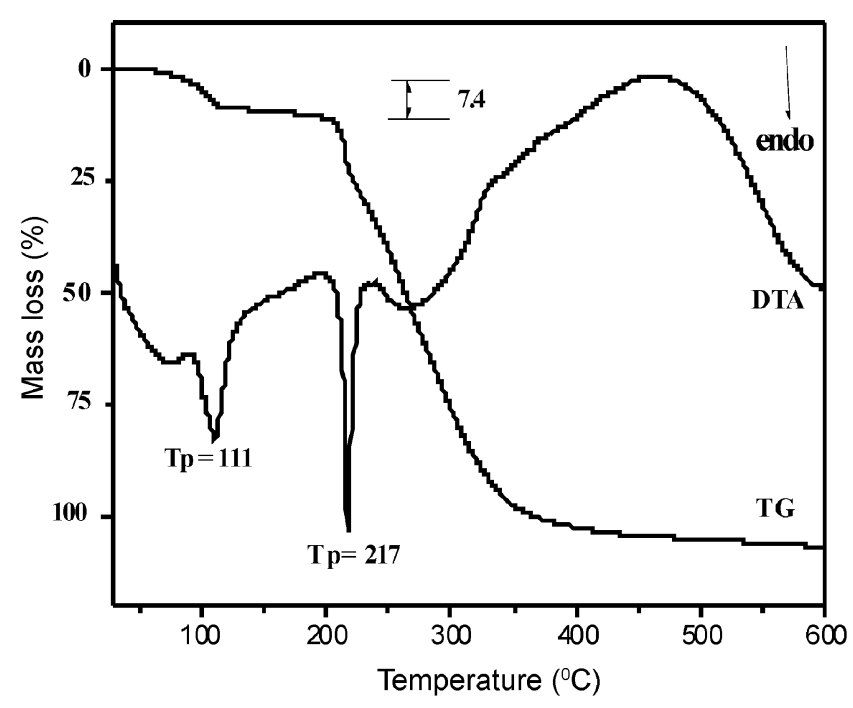

Figure 5. TG-DTA curves for (dbtmen) $\mathrm{Br}_{2} \cdot 2 \mathrm{H}_{2} \mathrm{O}, \mathbf{1}$ (decomposition in flowing Ar; $T p$ is peak temperature).

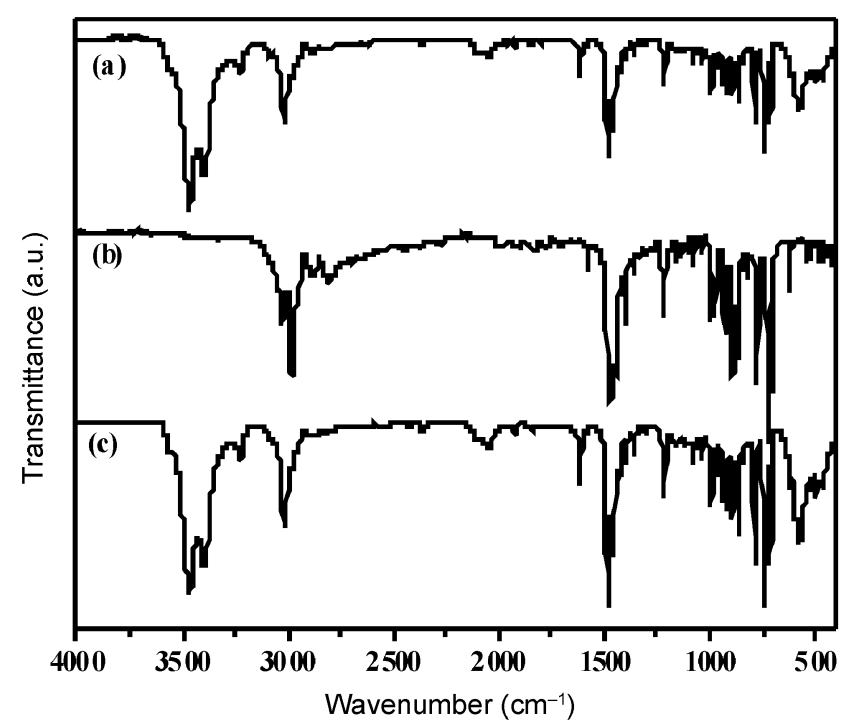

Figure 6. IR spectra of (a) pristine (dbtmen) $\mathrm{Br}_{2} \cdot 2 \mathrm{H}_{2} \mathrm{O}$, 1; (b) anhydrous (dbtmen) $\mathrm{Br}_{2}, 2$; (c) rehydrated (dbtmen) $\mathrm{Br}_{2}$. water, which are involved in the formation of the cyclic dibromide. The loss of water is complete at about $140^{\circ} \mathrm{C}$. On further heating the anhydrous compound starts decomposing endothermically $(T p=$ $218^{\circ} \mathrm{C}$ ) and pyrolysis till $600^{\circ} \mathrm{C}$ results in a small amount $(\sim 6 \%)$ of black residue of carbon indicating incomplete decomposition. 1 can be reversibly hydrated. Re-hydration behaviour of the dehydrated sample was studied using IR spectroscopy and X-ray powder diffraction. (dbtmen) $\mathrm{Br}_{2} \cdot 2 \mathrm{H}_{2} \mathrm{O}$ was heated to $140^{\circ} \mathrm{C}$ in an oven for the complete emission of crystal water and the IR spectrum of the calcined sample $\mathbf{2}$ showed the absence of the O-H bands at 3464, $3394 \mathrm{~cm}^{-1}$. In addition the bands at 941, 744 and $578 \mathrm{~cm}^{-1}$ in $\mathbf{1}$ are not observed in 2 . It has been reported that the gas phase vibrational spectra of the $\mathrm{Br}^{-}(\mathrm{HBr})_{n}(n=1-3)$ clusters exhibit signals at 888 and $976 \mathrm{~cm}^{-1}$ for the $\mathrm{H}$-bonded $\mathrm{Br}^{-}(\mathrm{HBr})_{2}$ fragment. ${ }^{36}$ Interestingly the missing signals in the anhydrous compound are observed when the calcined compound $\mathbf{2}$ is exposed to moisture indicating that these signals originate from the $\mathrm{H}$-bonded cyclic $\left\{\mathrm{O}_{2} \mathrm{Br}_{2}\right\}$ unit. The remaining signals in the spectrum of $\mathbf{2}$ are observed at the same positions as for the hydrated compound. On exposure to water vapour, the calcined compound $\mathbf{2}$ is converted to the original dihydrate as evidenced by the IR spectrum of the rehydrated compound (figure 6). The X-ray powder pattern of the calcined sample is very similar to that

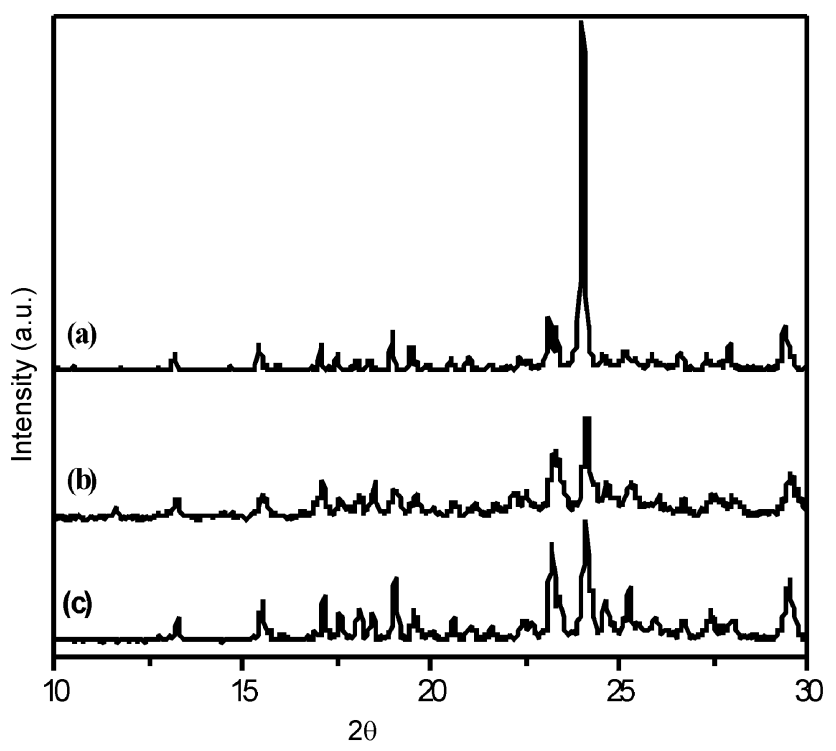

Figure 7. X-ray powder pattern of (a) pristine (dbtmen) $\mathrm{Br}_{2} \cdot 2 \mathrm{H}_{2} \mathrm{O}, 1$; (b) calcined (dbtmen) $\mathrm{Br}_{2} \cdot 2 \mathrm{H}_{2} \mathrm{O}, 2$, and (c) rehydrated (dbtmen) $\mathrm{Br}_{2}$. 
Table 3. Hydrogen-bonding geometry $\left(\AA\right.$, $\left.^{\circ}\right)$ for (dbtmen $) \mathrm{Br}_{2} \cdot 2 \mathrm{H}_{2} \mathrm{O}, \mathbf{1}$.

\begin{tabular}{lccccc}
\hline $\mathrm{D}-\mathrm{H} \cdots \mathrm{A}$ & $d(\mathrm{D}-\mathrm{H})$ & $d(\mathrm{H} \ldots \mathrm{A})$ & $d(\mathrm{D} \ldots \mathrm{A})$ & $<$ DHA & Symmetry code \\
\hline $\mathrm{O} 1-\mathrm{H} 1 \mathrm{O} 1 \cdots \mathrm{Br} 1$ & $0 \cdot 840$ & $2 \cdot 528$ & 3.359 & $170 \cdot 23$ & \\
$\mathrm{O} 1-\mathrm{H} 2 \mathrm{O} 1 \cdots \mathrm{Br} 2$ & 0.840 & 2.498 & 3.337 & 176.31 & $x, y, z-1$ \\
$\mathrm{O} 2-\mathrm{H} 1 \mathrm{O} 2 \cdots \mathrm{Br} 2$ & $0 \cdot 840$ & 2.497 & 3.329 & 170.61 & \\
$\mathrm{O} 2-\mathrm{H} 2 \mathrm{O} 2 \cdots \mathrm{Br} 1$ & 0.840 & 2.472 & 3.306 & 171.77 & $x, y, z+1$ \\
\hline
\end{tabular}

of the starting dihydrate (figure 7) indicating that the overall structure of $\mathbf{1}$ still remains intact after the water molecules are removed.

\section{Conclusions}

The organic diammonium dibromide (dbtmen) $\mathrm{Br}_{2} \cdot 2 \mathrm{H}_{2} \mathrm{O} 1$ has been synthesized by reacting tmen with benzyl bromide in $\mathrm{CH}_{3} \mathrm{CN}$. The hydrated dibromide has been unambiguously characterised by elemental analysis, spectroscopic techniques and Xray crystal structure determination. Compound $\mathbf{1}$ emits water on heating and reabsorbs water when the dehydrated sample is exposed to moisture. The structure of 1 consists of the (dbtmen $)^{2+}$ dication and a four-membered cyclic dibromide formed by $\mathrm{O}-$ $\mathrm{H} \cdots \mathrm{Br}$ hydrogen bonding interactions between crystal water molecules and bromide anions. The presence of the cyclic dibromide in the crystal structure of $\mathbf{1}$ as well as the tetraalkylation around $\mathrm{N}$ leads to a layer structure wherein the cations and anions are packed as alternating layers in the crystallographic $b c$ plane. It would be of interest to verify if such a layer like arrangement is the preferred structure motif for tetraalkylated ammonium compounds with other anions like molybdates, phosphates etc. Efforts in this direction are underway in our laboratories.

\section{Acknowledgements}

BRS thanks Prof K S Rane and Dr V S Nadkarni for helpful discussions and Mr P Raghavaiah for the CCDC search. The TG-DTA carrier used in this study was procured under a Department of Science and Technology, (DST) New Delhi supported project. We are grateful to the Department of Science and Technology, Govt. of India and the University Grants Commission, New Delhi for financial support.

\section{References}

1. Rao C N R, Natarajan S, Choudhury S, Neeraj S and Ayi A A 2001 Acc. Chem. Res. 3480
2. Ghosh S K and Bharadwaj P K 2004 Angew. Chem., Int. Ed. 433577

3. Ghosh S K and Bharadwaj P K 2004 Inorg. Chem. 43 5180; 6887

4. Manikumari S, Shivaiah V and Das S K 2002 Inorg. Chem. 416953

5. Supriya S, Manikumari S, Raghavaiah P and Das S K 2003 New J. Chem. 27218

6. Chakrabarti S and Natarajan S 2002 Cryst. Growth Design 2333

7. Ganesan S V and Natarajan S 2005 J. Chem. Sci. 117 219

8. Rao C N R, Natarajan S and Neeraj S $2000 \mathrm{~J}$. Am. Chem. Soc. 1222810

9. Ganesan S V and Natarajan S 2004 Inorg. Chem. 43 198

10. Meng H, Li G, Liu Y, Cui Y and Pang W $2004 \mathrm{~J}$. Solid State Chem. 1774459

11. Raghavaiah P, Supriya S and Das S K 2005 Cryst. Eng. Commun. 7167

12. Srinivasan B R, Dhuri S N, Näther C and Bensch W 2003 Indian J. Chem. A42 2735

13. Srinivasan B R, Näther C and Bensch W 2003 Acta Crystallogr. E59 m639

14. Srinivasan B R, Naik A R, Näther C and Bensch W 2004 Acta Crystallogr. E60 m1384

15. Srinivasan B R, Vernekar B K and Nagarajan K 2001 Indian J. Chem. A40 563

16. Srinivasan B R, Dhuri S N, Poisot M, Näther C and Bensch W 2004 Z. Naturforsch. B59 1083

17. Srinivasan B R, Dhuri S N, Näther C and Bensch W 2005 Inorg. Chim. Acta $\mathbf{3 5 8} 279$

18. Srinivasan B R, Näther C and Bensch W 2005 Acta Crystallogr. E61 m2454; Srinivasan B R, Näther C and Bensch W 2006 Acta Crystallogr. C62 m98

19. Srinivasan B R, Dhuri S N, Näther C and Bensch W 2002 Acta Crystallogr. E58 m622

20. Srinivasan B R, Dhuri S N, Näther C and Bensch W 2003 Acta Crystallogr. C59 m124

21. Srinivasan B R, Dhuri S N, Näther C and Bensch W 2003 Acta Crystallogr. E59 m681

22. Srinivasan B R, Poisot M, Näther C and Bensch W 2004 Acta Crystallogr. E60 i136

23. Srinivasan B R, Dhuri S N, Poisot M, Näther C and Bensch W 2005 Z. Anorg. Allge. Chem. 6311087

24. Srinivasan B R, Näther C, Dhuri S N and Bensch W 2006 Monats. Chem. 137 (in press)

25. Sheldrick G M 1994 SHELXS-97: Program for the solution of crystal structures, University of Gottingen, Germany 
26. Sheldrick G M 1997 SHELXL-97: Program for the refinement of crystal structures, University of Gottingen

27. Annan T A, Chadha R K and Tuck D G 1991 Acta Crystallogr. C47 151

28. Bondi A 1964 J. Phys. Chem. 68441

29. Baker M V, Bosnich M J, Williams C C, Skelton B W and White A H 1999 Aust. J. Chem. 52823

30. Weiss R, Reichel S, Handlke M and Hampel F 1998 Angew. Chem., Int. Ed. Engl. 37344

31. Arnold P L, Mungur S A, Blake A J and Wilson C 2003 Angew. Chem., Int. Ed. Engl. 425981
32. Kleinhenz S, Tulloch A A D and Danopoulos A A 2000 Acta Crystallogr. C56 e476

33. Haddad S F and Al-Far R H 2003 Acta Crystallogr. E59 o1444

34. Sundar T V, Parthasarathi V, Sarkunam K, Nallu M, Walfort B and Lang H 2004 Acta Crystallogr. C60 o464

35. Ihmels H, Leusser D, Pfeiffer M and Stalke D $1999 \mathrm{~J}$. Org. Chem. 645715

36. Pivonka N L, Kaposta C, Helden G, Meijer G, Wöste L, Neumark D M and Asmis K R 2002 J. Chem. Phys. 1176493 